\title{
Amyand's hernia associated with mesenteric chylous cyst in infant: a rare case report
}

\author{
Supangat ${ }^{1,4^{*}} \mathbb{D}$, Muhammad Yuda Nugraha ${ }^{2}$ and Meiske Margaretha ${ }^{3}$
}

\begin{abstract}
Background: Amyand's hernia is a rare condition approximately $0.4-0.6 \%$ of all inguinal hernias. Although rare, the Amyand's hernia is worthy of discussion since the variable presentation that make clinical challenge to diagnose especially in infant. A mesenteric chylous cyst is rare disease and has not been reported in Amyand's hernia.

Case presentation: We report an unusual case of Type II Amyand's hernia with an enlarging chylous mesenteric cyst on the retrocaecal in the anulus into canalis inguinalis. A-2-months old infant presented with enlarging mass in the right scrotal. During laparotomy exploration, we found inguinal sac with intestinal and appendix content in the $\mathrm{sac}$. In the edge site of the sac we found enlarging of mesenteric cyst on the retrocaecal in the anulus into canalis inguinalis. Based on the histopathology examination, the morphological feature is suitable for mesenteric chylous cyst appearance.
\end{abstract}

Conclusion: Presentation of mesenteric chylous cyst is rare, and there was no report about it in Amyand's hernia. This unusual presentation should be considered by the surgeon, especially pediatric surgeon, in Amyand's hernia cases.

Keywords: Hernia, Mesenteric cyst, Pediatric, Surgery

\section{Background}

Amyand's hernia is a rare condition approximately $0.4-0.6 \%$ of all inguinal hernias where the vermiform of appendix is found in inguinal hernia sac [1]. An incarcerated or strangulated hernia is commonly presenting in Amyand's hernia, but it is classified as several types for variable presentation. We report an unusual case of Type II Amyand's hernia with an enlarging chylous mesenteric cyst on the retrocaecal in the anulus into canalis inguinalis.

\section{Case presentation}

A-2-months old infant presented with enlarging mass in the right scrotal. On physical examination, the enlarging mass was found with diameter $10 \mathrm{~cm}$ non-fluctuant,

\footnotetext{
*Correspondence: drsupangat@unej.ac.id

${ }^{4}$ Faculty of Medicine, Universitas Jember, JI Kalimantan No 37, Krajan Timur, Sumber sari Kec Sumber sari, Jember 68121, East Java, Indonesia Full list of author information is available at the end of the article
}

non-erythematous which was fixed and mildly tender to palpation (Fig. 1). Based on hetero anamnesis, the patient vomited with green fluid before presenting into emergency department. The vital sign was steady in normal limit. During abdominal examination, there was decreasing of bowel sounds but there was no abdominal distention sign.

In the emergency department the patient underwent to take plain abdominal radiography. There was intestinal like appearance in the scrotal region and some dilated intestinal but no evidence of intestinal obstruction or aeration in the scrotal compartments (Fig. 2). The advance radiological examination cannot be performed since the patient's condition. All laboratory values were within normal limits. Based on the clinical examination and radiography the patient was diagnosed with Right Scrotum Hernia. After first initial treatment in the emergency department with normal fluid resuscitation, then patient was planned into laparotomy approach to treat the hernia. 


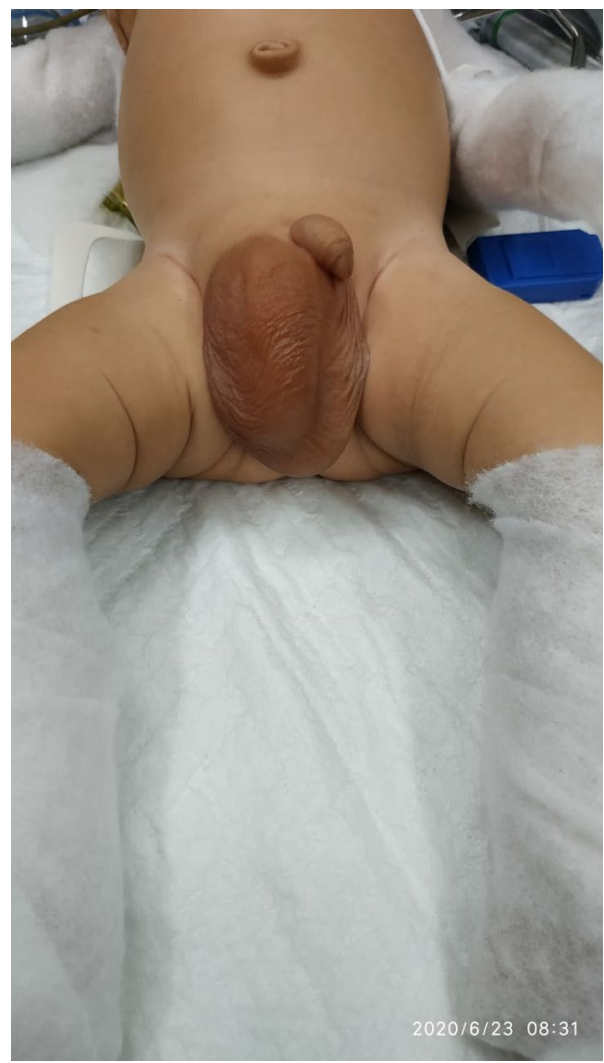

Fig. 1 Enlarging mass in the right scrotal

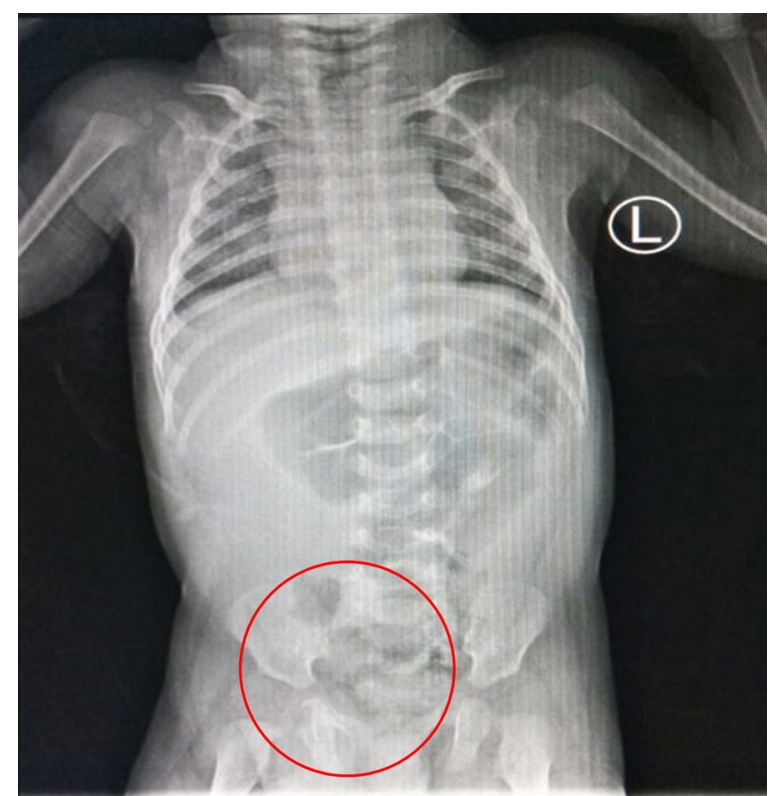

Fig. 2 Plain abdominal radiography
During laparotomy exploration, we found inguinal sac with intestinal and appendix content in the sac (Fig. 3a). The inflamed appendix but there was no perforation sign that indicate the type II of Amyand's Hernia as intraoperative diagnosis. In the edge site of the sac we found hyperemia mesenteric cyst on the retrocaecal in the canalis inguinalis (Fig. 3b). Appendectomy, cyst resection and hernia closure were done. Then the cyst resection was presented to histopathology examination.

Based on the histopathology examination, the cyst resection is form of a swollen connective tissue (red arrow in Fig. 4a) that coated with spindle-shaped cells resembling endothelial cells on the surface (blue arrow in Fig. 4a). Lymphoplasmasitic inflammatory cells appeared in the stroma then also moderate neutrophil PMN type (orange arrow in Fig. 4a) and dilated blood vessels (yellow arrow in Fig. 4a). There was also benign smooth muscle tissue and the large area of bleeding (Fig. 4b). There are no malignant signs on this resection. This morphological feature is suitable for Chylous cyst appearance.

\section{Discussion and conclusion}

In 1735 at the St. hospital George in London, dr. Claudius Amyand succeeded in carrying out the first appendicitis surgery in the world. The patient is an 11-year-old boy with a diagnosis of inguinal hernia combined with acute appendicitis. During the operation, dr. Amyand finds the appendix in the hernia sac [2]. This rare pathology is then given the name "Amyand Hernia" according to the name of the surgeon who first described it and treated it. The incidence of an Amyand's Hernia is less than 1\% of inguinal hernias with the most patients is male. In this case, the patient is infant and male. It is really challenging to diagnose Amyand's hernia in infant.

Amyand 's Hernia commonly located on the right side due to the location of the appendix. Approximately $0.1 \%$ of Amyand's Hernia cases, appendix could be inflamed [3]. Therefore, Losanoff et al. classified Amyand's hernias into four type. The type I is defined when there is no described appendix inflammation; type II describes acute appendicitis within the hernia sac; type III acute appendicitis complicated with peritonitis; and type IV acute appendicitis is accompanied by other diseases [4]. In this case, we found an acute appendiscitis during intraoperative but there was no sign of peritonitis. Then, the type of Amyand's Hernia in this case is classified as type II Amyand's Hernia.

Amyand's Hernia commonly performs as incarcerated inguinal hernias that make it very difficult to diagnose only by clinical assesment especially in infant. Preoperative diagnosis of Amyand's Hernia can be established using investigations in the form of ultrasound or CT scan. Mostly cases of Amyand's Hernia are diagnosed 




Fig. 3 a Appendix and intestinal in the inguinal sac, b Hyperemia mesenteric cyst (yellow arrow), post appendectomy (blue arrow) and caecum (red arrow) in the inguinal sac

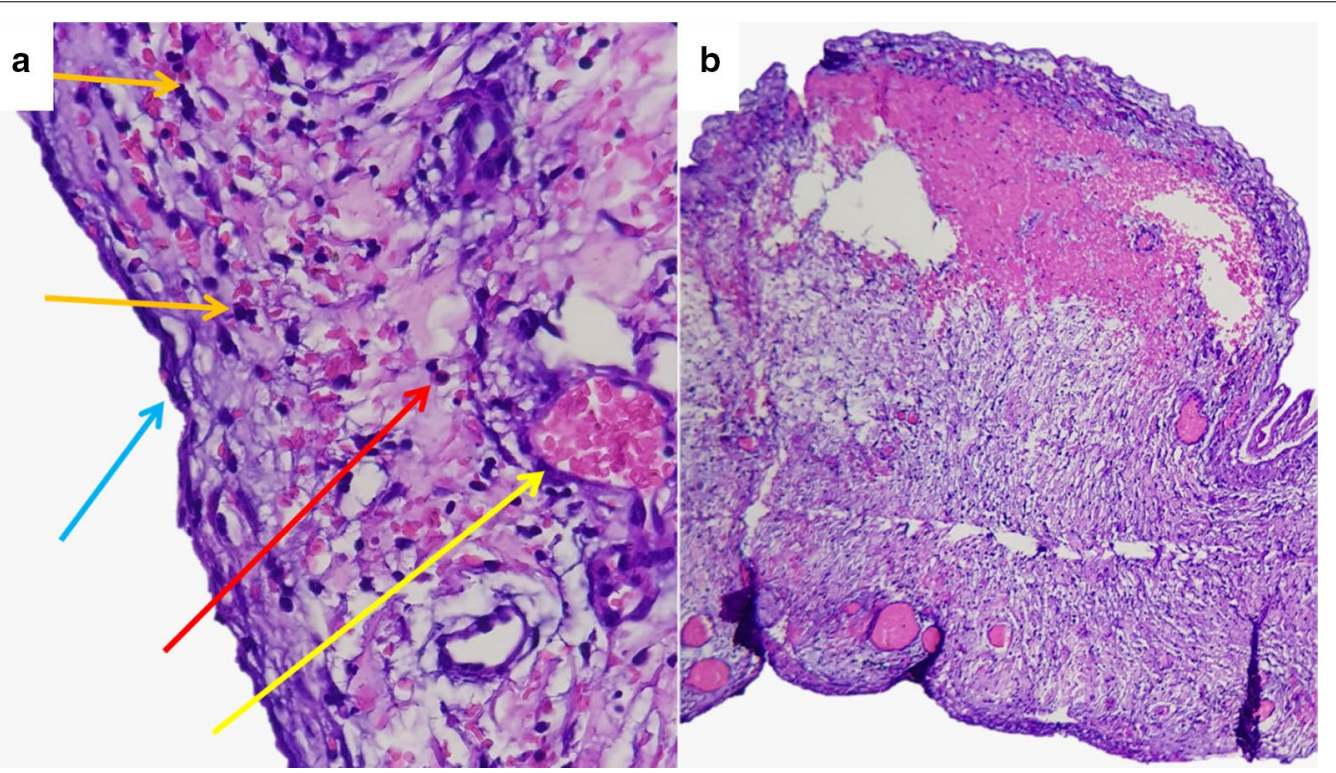

Fig. 4 Histopathology examination of cyst resection

intraoperatively during the operation process [5]. In this case, we diagnosed Amyand's Hernia intraoperatively. During preoperative diagnosis, we only performed scrotal hernia as a diagnosis based on clinicaly and plain abdominal radiography since abdominal ultrasound or CT Scan cannot be performed.

In Amyand's Hernia, the appendix can be found together with the right cecum or colon in the hernia sac. In some cases it can also be found a bladder, ovary, fallopian tube, omentum or meckel diverticulum in the hernia sac [6]. In this case we found mesenteric cyst in the hernia sac. After histopathology examination, the type of cyst is classified as mesenteric chylous cyst. The presenting of mesenteric chylous cyst in Amyand's hernia hasnot been reported before.

Mesenteric cysts is a rare pathologic entity that identified in approximately 1 out of 100,000 adult and 1 in 20,000 paediatric in hospital admissions [7]. A mesenteric chylous cyst is the type of mesentery cyst which may extend from the base of the mesentery into the retroperitoneum [8]. A mesenteric chylous cyst could be totally asymptomatic or present with unspecific abdominal 
symptoms. It is a rare disease, but surgeons must consider the diagnosis in the presence of a cystic abdominal tumor [9].

Amyand's hernia has variability in presentation that makes it difficult to diagnose clinically in infant and mostly identified intraoperatively. Presentation of mesenteric chylous cyst is rare, and there was no report about it in Amyand's hernia. This unusual presentation should be considered by the surgeon, especially pediatric surgeon, in Amyand's hernia cases.

\section{Abbreviations}

CT scan: Computed tomography scan; PMN: Polymorphonuclear.

\section{Acknowledgements}

Not applicable

\section{Authors' contributions}

MYN drafted the manuscript. S and MM provided expert opinion and edited the manuscript and article guarantor. All authors have read and approved the manuscript and ensure that this is the case.

\section{Funding}

No funding was applied for this study.

\section{Availability of data and materials}

Not applicable.

\section{Ethics approval and consent to participate}

The study involving a human participant to report was approved by the ethics committee of Faculty of Medicine, Jember University. Written consent was obtained from the patient's parents.

\section{Consent for publication}

Written informed consent was obtained from the patient guardian for publication of this case report and accompanying images since the patient is under 16 years old. A copy of the written consent is available for review by the Editor of this journal.

\section{Competing interests}

The authors declare no conflict of interest.

\section{Author details}

${ }^{1}$ Division of Pediatric Surgery, dr. Soebandi Regional Hospital-Faculty of Medicine, Jember University, Jember, East Java, Indonesia. ${ }^{2}$ Faculty of Medicine, Jember University, Jember, East Java, Indonesia. ${ }^{3}$ Division of Pathological Anatomy, dr. Soebandi Regional Hospital, Jember, East Java, Indonesia.

${ }^{4}$ Faculty of Medicine, Universitas Jember, Jl Kalimantan No 37, Krajan Timur, Sumber sari Kec Sumber sari, Jember 68121, East Java, Indonesia.

Received: 14 July 2020 Accepted: 4 November 2020

Published online: 02 December 2020

References

1. Burgess PL, Brockmeyer JR, Johnson EK. Amyand hernia repaired with Bio-A: a case report and review. J Sur Educ. 2011;68:62-6.

2. Amyand C. Of an inguinal rupture, with a pin in the appendix caeci, incrusted with stone; and some observations on wounds in the guts. Philos Trans R Soc Lond. 1736;39:329-36.

3. Ballas K, Kontoulis T, Skouras C, Triantafyllou A, Symeonidis N, Pavlidis T, et al. Unusual findings in inguinal hernia surgery: report of 6 rare cases. Hippokratia. 2009:13:169-71.

4. Losanoff JE, Basson MD. Amyand hernia: what lies beneath-a proposed classification scheme to determine management. Am Surg. 2007;73:1288-90

5. Michalinos A, Moris D, Vernadakis S. Amyand's hernia: a review. Am J Surg. 2014;207(6):989-95

6. Goyal S, Shrivastva M, Verma RK, Goyal S. "Uncommon contents of inguinal hernial sac": a surgical dilemma. Indian J Surg. 2015;77(Suppl 2):305-9.

7. Tebala GD, Camperchioli I, Tognoni V, Noia M, Gaspari AL. Laparoscopic treatment of a huge mesenteric chylous cyst. JSLS. 2010;14:436-8.

8. Lee DLP, Madhuvrata P, Reed MW, Balasubramanian SP. Chylous mesenteric cyst: a diagnostic dilemma. Asian J Surg. 2016:39:182-6.

9. Dioscoridi L, Perri G, Freschi G. Chylous mesenteric cysts: a rare surgical challenge. J Surg Case Rep. 2014;2014(3):rju012.

\section{Publisher's Note}

Springer Nature remains neutral with regard to jurisdictional claims in published maps and institutional affiliations.
Ready to submit your research? Choose BMC and benefit from

- fast, convenient online submission

- thorough peer review by experienced researchers in your field

- rapid publication on acceptance

- support for research data, including large and complex data types

- gold Open Access which fosters wider collaboration and increased citations

- maximum visibility for your research: over 100M website views per year

At $\mathrm{BMC}$, research is always in progress.

Learn more biomedcentral.com/submissions 